\title{
Strategi Menangani Kemelut Golongan Anti Hadis (GAH)
}

\author{
Mohd Al'Ikhsan Ghazali, Siti Salwa Md. Sawari*, Muhaidi Mustaffa Al-Hafiz, Mohd Hambali Rashid
}

Fakulti Tamadun Islam, Universiti Teknologi Malaysia Kuala Lumpur, Jalan Semarak, 54100 Kuala Lumpur

*Corresponding author: ssalwa35@live.utm.my

\begin{abstract}
Abstrak
Penyebaran pemikiran anti hadis di Malaysia kini semakin membimbangkan. Sektor pendidikan juga turut terkesan daripada bahang pemikiran sesat ini. Umat Islam sepatutnya menyedari bahawa pemikiran ini telah cuba merosak Islam secara keseluruhannya. Mereka telah berjaya melatih kader-kader di kalangan cendekiawan Islam sendiri dalam usaha merealisasikan pemikiran mereka. Demi menjaga kesucian Islam, pemikiran anti hadis ini haruslah di hapuskan. Oleh itu tujuan kajian ini dilaksanakan bagi mengenal pasti langkah-langkah penyelesaian yang telah diamalkan oleh pelbagai pihak di Malaysia. Metode kajian perpustakaan dan temu bual telah digunakan oleh pengkaji bagi menyelesaikan permasalahan kajian ini. Di dalam kajian ini, pengkaji telah menemui pelbagai langkah-langkah pembanterasan dan penyelesaian bagi kemelut pemikiran anti hadis yang mana telah dilaksanakan oleh pihak berkuasa dan masyarakat sendiri. Dapatan daripada kajian boleh menjadi garis panduan dalam memaksimumkan pembanterasan kemelut Golongan Anti Hadis daripada tersebar luar. Bukan itu sahaja kajian ini di harapkan dapat membantu para ahli akademik untuk mengenalpasti kesan-kesan penyelesain yang telah terlaksana.
\end{abstract}

Kata kunci: Golongan anti hadis (GAH); hadis; islam

Abstract

Propagation of anti-hadith group in Malaysia has increasingly alarming. The education sector also suffers a heat of this thinking. Muslims should realize that this thought tried destroying Islam as a whole. They have trained cadres among Muslim themselves in an effort to spread their thought. In order to protect the sanctity of Islam, thought against hadith $\mathrm{t}$ should be eradicated. The purpose of this study carried out to identify the measures proposed solution that has been implementing by various parties. Methods of library research and interviews have been used by researchers to solve problems of this research. In this study, researchers found numerous prevention and solutions to the crisis of thought against hadith which have been implemented by the authorities and the society itself. Hopefully, the findings of the study can serve as a guideline to maximizing the eradication of turmoil spread to Anti-Hadith from outside . Not only that this study is expected to help academics to identify the effects of a the proposed solution that has been accomplished.

Keyword: Anti-hadis group; hadith; islam

(C) 2016 Penerbit UTM Press. All rights reserved

\subsection{PENDAHULUAN}

Umat Islam sepatutnya menyedari bahawa adanya gerakan yang cuba merosakkan dan menghapuskan Islam secara keseluruhannya (Nor, 2011; Sulidar, 2010). Mereka telah berjaya melatih kader-kader di kalangan cendekiawan Islam sendiri dalam usaha merealisasikan impian mereka (Nurfajriyani, 2015). Gerakan yang paling menyerlah pada abad ini adalah di panggil dengan nama Golongan Anti Hadis. Demi menjaga kesucian Islam, pemikiran anti hadis ini haruslah di hapuskan. Walaupun sesetengah pihak mengatakan isu ini adalah sensitif untuk di bincangkan, namun ia amat perlu di banteras kerana ia berkait dengan akidah umat Islam. Tambahan pula, Golongan Anti Hadis (GAH) giat berusaha menyebarkan fahaman mereka dan sekiranya umat Islam sendiri tidak peka dengannya, maka semakin ramailah di kalangan mereka yang akan terpengaruh.

Terdapat sebahagian masyarakat awam yang menjadi keliru dengan pandangan-pandangan baru yang cuba diketengahkan oleh gerakan ini (Al'Ikhsan Ghazali \& Sawari, 2014). Terdapat di kalangan mereka, golongan yang mudah mempercayai atau hampir mempercayainya. Kedapatan juga orang awam yang telah berfikiran macam mereka dan telah bertindak dengan cara mereka dan pada waktu yang sama mereka mengatakan tidak bersetuju dengan pemikiran anti hadis. Oleh yang demikian kajian ini dilaksanakan bagi menyelongkar langkah-langkah pembanterasan GAH ini.

\subsection{SOROTAN KAJIAN}

Golongan Antihadis (Gah)

Menolak al-sunnah merujuk kepada perkataan bahasa Arab yang membawa maksud golongan Antihadis. Penjelasan berhubung dengan definisi ini akan dimulakan dengan pendefinisian golongan, anti dan munkir' dari segi bahasa. Kemudian diikuti dengan penjelasan definisi hadis dan sunah dari segi bahasa dan istilah. Menurut Kamus Dewan (2002) 'golongan' adalah kumpulan atau kelompok dan anti 
pula adalah awalan yang bermaksud melawan, membantahi, menentang, tidak menyetujui. Perkataan hadis dari segi bahasa ialah baru atau khabar atau apa yang diucapkan oleh seorang pengucap (Khalil al-Jur t.th.). Munkir pula adalah isim facil (kata pembuat) daripada perkataan ankara yunkiru inkaran ( أنكر ينكر إنكار ). Ingkar sesuatu ialah jahil tentangnya dan ingkar nikmat pula ialah mengkufurinya (Khalil al-Jur t.th.) sebagaimana firman Allah S.W.T. (Al-Qur'an, surah al-Nahl 16:83), Maksudnya: "Mereka mengetahui nikmat Allah (yang melimpah-limpah itu), kemudian mereka tergamak mengingkarinya dan kebanyakan mereka pula ialah orang-orang yang kufur ingkar". Dalam Lisan al-cArab : Ingkar adalah sama dengan juhud iaitu mengingkari dalam keadaan ia tahu (Ibn Manzur t.th.). Menurut Kamus Dewan (2002) ingkar mempunyai tiga maksud, pertama; tidak membenarkan (mengaku), menafikan, menyangkal dan mungkir, kedua; enggan, tidak menurut dan tidak mahu dan ketiga; penafian, penyangkalan dan perihal memungkiri.

Sunah asalnya ialah jalan (al-Nawawi t.th.). Sunah juga adalah 'sirah' dan 'jalan biasa' sama ada baik atau buruk (Ibn Manzur t.th.). Perkataan sunah yang membawa maksud 'jalan' terdapat di beberapa tempat dalam Al-Qur'an, salah satunya ialah firman Allah S.W.T.(Al-Qur'an, surah al-Nisa'4:26), Maksudnya: Allah menghendaki (dengan apa yang telah diharamkan dan dihalalkan dari kaum perempuan itu) ialah untuk menerangkan (Syariat-Nya) dan untuk menunjukkan kepada kamu jalan-jalan aturan orang-orang yang dahulu daripada kamu (Nabi-nabi dan orang-orang yang salih, supaya kamu mengikutinya), dan juga untuk menerima taubat kamu. Dan (ingatlah) Allah Maha Mengetahui lagi Maha Bijaksana. Hadis dari segi istilah ialah segala yang disandarkan kepada Nabi S.A.W. sama ada perkataan, perbuatan, pengakuan, sifat semulajadi dan akhlak (Nur al-Din Itr 1996). Sunah menurut Imam al-Nawawi (t.th.) ialah hadishadis yang diriwayatkan daripada Nabi S.A.W.

Menurut al-Hafiz Ibn Hajar (t.th.). sunah, hadis, khabar dan athar merupakan lafaz-lafaz yang hampir mempunyai makna yang satu (ulama berselisih pandangan dalam perkara ini) iaitu segala yang disandarkan kepada Nabi S.A.W. , para sahabat dan para tabicin sama ada perkataan, perbuatan, pengakuan dan sifat. Hadis dan sunah adalah sama takrifnya dari segi istilah di sisi kebanyakan ulama hadis terutama ulama mutakhir (Baha' al-Din 1999). Takrif sunah yang dinyatakan di atas itu adalah takrif di sisi ulama hadis. Manakala ulamaulama yang mempunyai disiplin ilmu yang lain menakrifkan sunah mengikut disiplin ilmu mereka. Di sisi ulama fekah, sunah atau mandub ialah apa yang dituntut oleh syarak ke atas seorang yang mukallaf untuk melaksanakannya dengan tuntutan yang tidak wajib. Ia juga boleh ditakrifkan:

\section{Dalil-Dalil Penghujahan Sunah}

Terdapat banyak dalil-dalil dalam Al-Qur'an yang menunjukkan bahawa umat Islam mesti mengikuti Nabi Muhammad S.A.W. dalam semua perkara seperti perkataan, perbuatan, tingkah laku dan sebagainya. Antara dalil-dalil tersebut sebagaimana yang telah disusun oleh Dr. Abdul al-Karim Zaidan (2001) ialah:

i. Secara jelas dinyatakan dalam Al-Qur'an bahawa Nabi Muhammad S.A.W. tidak bercakap menurut hawa nafsunya sebaliknya bercakap berdasarkan wahyu yang diturunkan kepadanya. Firman Allah S.W.T. (Al-Qur'an, al-Najm 53: 3-4) : Maksudnya: Dan ia tidak memperkatakan (sesuatu yang berhubung dengan agama Islam) menurut kemahuan dan pendapatnya sendiri. Segala yang diperkatakannya itu (sama ada Al-Qur'an atau hadis) tidak lain hanyalah wahi yang diwahikan kepadanya.

ii. Perintah mentaati Rasullullah S.A.W. Sebagaimana firman Allah S.W.T.( Al-Qur'an, surah Al cImran 3:32) : Maksudnya: Katakanlah (wahai Muhammad): "Taatlah Allah dan Rasul-Nya. Oleh itu, jika kamu berpaling (menderhaka), maka sesungguhnya Allah tidak suka kepada orang-orang yang kafir.

iii. Mentaati Rasullullah S.A.W. bererti taat kepada Allah S.W.T. Firman Allah S.W.T. (Al-Qur'an, surah al-Hashr 59:7) : Maksudnya: Dan apa jua perintah yang dibawa oleh Rasullullah S.A.W. kepada kamu maka terimalah serta amalkan, dan apa jua yang dilarangnya kamu melakukannya maka patuhilah larangannya.

Ayat ini merupakan dalil yang menunjukkan keotoritian hadis untuk mengutarakan sesuatu yang tidak dinyatakan dalam Al-Qur'an. Diriwayatkan daripada Imam Shafie R.H.M. bahawa ketika beliau sedang duduk mengajar orang ramai di Masjid al-Haram beliau berkata: Tidak kamu bertanyakan aku satu soalan pun melainkan aku akan menjawab dengan Kitab Allah. Lalu kata seorang lelaki: Apa hukum seorang yang sedang dalam ihram membunuh seekor tebuan? Jawab Imam Shafie:

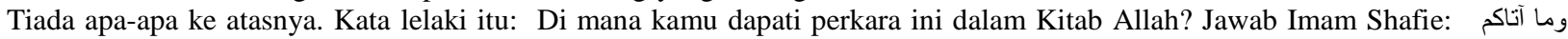
kemudian beliau menyebut sanad sehingga kepada Saidina Umar bahawa beliau berkata: Harus bagi seorang yang berihram membunuh tebuan (Abu Shahbah 1989).

iv. Wajib dikembalikan semua pertelingkahan kepada Allah iaitu Kitab-Nya dan kepada Rasul iaitu sunahnya. Firman Allah S.W.T. (Al-Qur'an, surah al-Nisa' 4:59), Maksudnya: Kemudian jika kamu berbantah-bantah (berselisihan) dalam sesuatu perkara, maka hendaklah kamu mengembalikannya kepada kepada (Kitab) Allah dan (sunah) RasulNya - jika kamu benar beriman kepada Allah dan hari akhirat. Yang demikian adalah lebih baik (bagimu), dan lebih elok pula kesudahannya.

v. Wajib merujuk dan menerima penghakiman Rasul ketika berlaku kekhilafan. Firman Allah S.W.T. (Al-Qur'an, surah al-Nisa' 4:65) Maksudnya: Maka demi Tuhanmu (wahai Muhammad) mereka tidak disifatkan beriman sehingga mereka menjadikan engkau hakim dalam mana-mana perselisihan yang timbul di antara mereka, kemudian mereka tidak merasa di hati sesuatu keberatan dari apa yang telah engkau hukumkan, dan mereka menerima keputusan itu dengan sepenuhnya.

vi. Tiada pilihan lagi bagi seorang muslim melainkan menerima ketetapan Allah dan Rasul-Nya. Firman Allah S.W.T. (Al-Qur'an, surah al-Ahzab 33:36) :Maksudnya:Dan tidaklah harus bagi orang-orang yang beriman, lelaki dan perempuan- apabila Allah dan Rasul-Nya menetapkan sesuatu keputusan mengenai sesuatu perkara-(tidaklah harus mereka) mempunyai hak memilih ketetapan sendiri mengenai urusan mereka. Dan sesiapa yang tidak taat kepada hukum Allah dan rasul-Nya maka sesungguhnya ia telah sesat dengan kesesatan yang jelas nyata.

vii. Amaran akan dikenakan azab yang pedih bagi orang yang mencanggahi Rasullullah S.A.W. Firman Allah S.W.T. (Al-Qur'an, surah al-Nur 24:63): Maksudnya: Oleh itu, hendaklah mereka yang mengingkari perintahnya, beringat serta berjaga-jaga jangan mereka ditimpa bala bencana atau ditimpa azab seksa yang tidak terperi sakitnya.

viii. Allah S.W.T. telah memberi kuasa kepada Rasullullah S.A.W. untuk menjelaskan hukum-hakam Al-Qur'an, ini adalah disebabkan di dalam Al-Qur'an itu terdapat hukum-hukum yang umum yang perlu di perjelaskan lagi. Firman Allah S.W.T. (AlQur'an, al-Nahl 16:44), Maksudnya: Dan kami pula turunkan kepadamu (wahai Muhammad) Al-Qur'an yang memberi 
peringatan, supaya engkau menerangkan kepada umat manusia akan apa yang telah diturunkan kepada mereka dan supaya mereka memikirkannya. GAH yang mempercayai Al-Qur'an sepatutnya juga beriman dengan hadis-hadis Rasullullah S.A.W. Semua dalil-dalil yang dinyatakan dan juga dalil-dalil yang lain adalah jelas mengarahkan umat Islam menjadikan sunah Nabi S.A.W. sebagai panduan dalam apa jua bidang. Sikap mereka yang membelakangi perintah Al-Qur'an itu menggambarkan mereka juga sebenarnya anti Al-Qur'an. Mereka sebenarnya berinteraksi dengan Al-Qur'an mengikut akal dan hawa nafsu mereka, menyebabkan mereka beriman dengan sebahagian Al-Qur'an kemudian menolak sebahagian yang lain. Sikap sebegini amat dimurkai oleh Allah S.W.T. sebagaimana firmanNya (Al-Qur'an, al-Baqarah, 2:85), Maksudnya: $\square$ Sesudah itu maka patutkah kamu percaya kepada sebahagian (dari isi) Kitab Taurat dan mengingkari akan sebahagian yang lain? Maka tiadalah balasan bagi orang yang berbuat demikian itu dari antara kamu, selain daripada kehinaan hidup di dunia, dan pada hari kiamat akan ditolak mereka ke dalam azab seksa yang amat berat.

\section{Sejarah Penolakan Hadis}

Penolakan hadis di zaman moden bermula selepas penjajahan barat ke atas negara-negara Islam, seperti Iraq, Mesir, India dan Pakistan. Sambil menjajah mereka menyebar fahaman dan aliran mereka (Habeeb 2006). Antara ajaran mereka ialah penolakan sunah dan Al-Qur'an sudah memadai, pada hakikatnya apa yang diinginkan mereka ialah penolakan agama Islam secara keseluruhan sama ada Al-Qur'an mahu pun sunah (al-Zahrani 1992). Ramai di kalangan cendikiawan Islam telah terpengaruh dan menjadi tali barut mereka terutama apabila mereka pergi menuntut ilmu di Eropah. Antara pengikut ajaran Goldziher yang mashyur ialah Dr. Ali Hasan Abdul Kadir, Toha Hussin (1889-1973), Dr. Ahmad Amin (1886-1954), Rasyad Khalifa dan Dr. Abu Rayyah.

Sejarah telah merekodkan bahawa pemikiran anti hadis telah mula sejak dari zaman para sahabat lagi (Ghazali, Yusof \& Sawari, 2016). Namun dengan kebijaksanaan para sahabat, gerakan ini dapat di lupuskan. Ia kembali semula wujud pada abad ke-2 dan telah ditangani dengan jayanya oleh Imam Shafie (Abdul Karim Ali 2007). Menurut Dr. Mustaffa al-SibaCie (1985), orang pertama berdepan dengan golongan ini adalah Imam Shafie r.h.m. yang telah memuatkan perdebatannya dengan seorang yang berfahaman anti hadis dalam bukunya al-Um. Beliau juga telah membincangkan dengan panjang lebar berkenaan dengan penghujahan khabar ahad dalam kitabnya alRisalah (Ghazali, Yusof \& Sawari, 2015).

Ulama-ulama Islam mula tampil ke depan menjawab isu ini dalam usaha menjaga kesucian Islam. Antara ulama Islam di peringkat global yang menjawab isu ini ialah Dr. Mustaffa al-Sibaci dalam bukunya al-Sunnah wa Makanatuha fi al-Tashric al-Islami. Beliau telah menyatakan sejarah bermulanya penolakan hadis dan kemudian menyatakan shubhah-shubhah yang dilontarkan oleh golongan pengingkar sunah. Beliau juga menjawab shubhah-shubhah yang telah ditimbulkan itu. Ulama Islam kedua ialah Dr. Muhammad Mustaffa al-cAzomi dalam bukunya Dirasat fi al-Hadith al-Nabawi wa Tarikh Tadwinihi”. Beliau memulakan kitabnya dengan penakrifan sunah dan diikuti dengan kedudukan sunah dalam Islam. Selepas itu secara khusus membincangkan sejarah pengingkaran sunah di zaman lampau dan diikuti pengingkarannya di zaman moden. Turut dibincangkan di dalam bukunya ialah sejarah penulisan hadis, pengajian hadis nabawi, perbahasan tentang isnad dan kesahihan hadis. Dalam perbahasan tentang isnad dan kesahihan hadis diutarakan pandangan orientalis berhubung dengan kedua-dua perkara berkenaan. Ulama-ulama di Malaysia juga turut terpanggil untuk menjawab kekeliruan-kekeliruan yang ditimbulkan oleh gerakan anti hadis. Setelah terbit buku Hadis Satu Penilaian Semula karangan Kasim Ahmad, para cendikiawan Islam di Malaysia telah bangkit menjawab dan mengkritik buku tersebut. Banyak buku-buku telah diterbitkan sebagai jawapan kepada buku Hadis Satu Penilaian Semula.

Majlis Agama Islam Kelantan (MAIK 1986) telah menerbitkan sebuah buku bertajuk Salah Faham Terhadap Hadis: Satu Penjelasan. Penerbitan buku ini adalah untuk menjelaskan mengenai kekeliruan dan pandangan-pandangan menyeleweng berkenaan dengan kedudukan hadis. Pada muqaddimah buku ini dipaparkan pandangan-pandangan menyeleweng GAH, asal usul pemikiran anti hadis yang bermula dengan orientalis, kedudukan dan kepentingan hadis dalam Islam, kekeliruan yang disengajakan, cara sahabat menerima hadis dan himpunan hadis di zaman sahabat. Paparan berikutnya ialah berkenaan dengan kewajipan mentaati sunah kerana ia adalah ajaran dari Allah S.W.T. dan Rasullullah S.A.W. Kemudian dimuatkan tajuk berhubung dengan sunah sebagai hikmah sumber akidah dan hukum sebelum disusuli dengan keteguhan sunah dari segi sejarah dan keselarasannya dengan Al-Qur'an dan akal. Tajuk sunah punca akidah dan hukum menyusul selepas itu sebelum diakhiri dengan seruan kembali kepada Al-Qur'an dan sunah.

Bahagian Hal Ehwal Islam (BAHEIS 1987), Jabatan Perdana Menteri telah menerbitkan sebuah buku yang bertajuk Kedudukan Sunah Dalam Syariat Islam pada 1987. Buku ini secara khususnya menjelaskan keotoritian sunah selain daripada menyatakan sejarah penentangan terhadap sunah di zaman lampau dan di zaman kini. Buku ini diakhiri dengan memuatkan pemikiran-pemikiran liar terhadap hadis dan jawapan-jawapannya.

Said Ibrahim (1987) ketika menjadi mufti Sabah telah menulis sebuah buku yang berjodol Penolakan Terhadap Penilaian Semula Hadis. Di awal bukunya beliau telah mengemukakan empat hujah yang pakai oleh Kassim Ahmad dalam menegakkan pemikirannya dan kemudian beliau mematahkan hujah-hujah berkenaan. Berikutnya dimuatkan tajuk berhubung dengan menolak dakwaan hadis bercanggah dengan Al-Qur'an. Sejurus selepas itu ditonjolkan bahawa hadis bukan suatu penyelewengan sebelum beliau membahaskan berkenaan dengan hadis sebagai sumber perundangan kedua Islam. Akhirnya beliau mengajak pembaca mengenal hadis Nabi S.A.W. yang perbahasannya meliputi pembahagian hadis, sejarah dan para pengumpul hadis.

Datuk Prof. Dr. Mahmud Zuhdi (1994) telah menyusun sebuah buku yang bertajuk Beberapa Pemikiran Tentang Ijtihad, Islah dan Tajdid. Buku ini menghimpunkan beberapa artikel yang antaranya telah diterbitkan oleh Dewan Budaya pada 1986. Artikel-artikel yang berkenaan dengan ijtihad, islah dan tajdid itu ditulis oleh Kassim Ahmad, Mahfodz Mohamad, Mahmood Zuhdi sendiri, S. Othman Kelantan dan A. Ghani Ismail.

Dalam sebuah buku yang bertajuk Anti hadis Jarum Yahudi karangan Hj. Isa Ismail dan Yusof Hj. Wanjor (1996) memaparkan pelopor utama gerakan anti hadis iaitu Goldziher, gerakan anti hadis di Mesir, Amerika, penyelewengan-penyelewengan golongan ini dan juga penafsiran Al-Qur'an dengan cara mereka. Ustaz Hafiz Firdaus Abdullah (2002) pula menyenaraikan syubhah-syubhah golongan ini dan kemudian menjawabnya dalam bukunya 20 Hujah Golongan Anti hadis dan Jawapannya.

Dalam kertas kerja yang bertajuk Pemikiran Anti hadis dan Perkembangan Semasa, Dr. Habeeb Rahman Ibramsa (2005) telah memuatkan sejarah awal benih-benih kemunculan gerakan anti hadis bermula di zaman sahabat dan zaman Imam Syafie. Kemudian beliau menyambung dengan perkembangan gerakan anti hadis di kurun 19 yang mula dicetus oleh orientalis Barat dan penggerak utama mereka 
ialah Goldziher. Beliau turut menyenaraikan pelopor-pelopor dan pengasas-pengasas gerakan anti hadis di kalangan umat Islam sendiri. Antara pelopor yang terkenal ialah Dr. Rashad Khalifa yang telah mempengaruhi Dr. Kassim Ahmad sehingga bermulanya gerakan ini di Malaysia.

Najah Nadiah (2005) dalam kertas kerjanya Diayah Anti hadis Dalam Internet telah mendedahkan dua laman web anti hadis yang digunakan oleh gerakan terbabit untuk menyebarkan dakyah mereka. Alamat laman web tersebut ialah www.e-bacaan.com dan www.stormloader.com/qsmjqm. Laman ini muncul setelah buku kontrovesinya Hadis: Satu Penilaian Semula di haramkan dan persatuan yang ingin ditubuhkan iaitu Jemaah Al-Qur'an Malaysia (JAM) tidak boleh didaftarkan kerana di bantah oleh Pusat Islam dan Majlis Agama Islam Negeri seluruh negara. Di dalam laman web berkenaan terdapat prinsip-prinsip pegangan mereka, bibliografi pengasas dan tajuk-tajuk seperti politik, ekonomi, sains, agama, kritikan, falsafah dan umum. Antara perkara penting yang terdapat di dalam laman web berkenaan ialah diayah-diayah mereka. Mereka kemukakan pandangan mereka dengan berdalilkan terjemahan Al-Qur'an mengikut versi mereka. Satu lagi cara mereka menyebarkan ajaran mereka melalui internet ini ialah dengan cara e-mail dan e-groups. Interaksi dua hala ini memudahkan lagi mereka mempengaruhi golongan yang tidak mantap asas agamanya.

Deden Suparman (2003) dalam tesis sarjananya yang bertajuk Anti hadis Dan Ingkar Sunah: Suatu Kajian Perbandingan Antara Malaysia dan Indonesia telah menjalankan kajian berhubung dengan latar belakang GAH di kedua-dua negara, menjawab persoalanpersoalan yang ditimbulkan oleh mereka, menjelaskan perbezaan antara makna hadis dari sudut bahasa dan istilah, menjelaskan perkaitan antara Al-Qur'an dengan hadis, tingkatan hadis, mendedahkan dan membetulkan fahaman-fahaman GAH dan membuat perbandingan antara GAH di Malaysia dan di Indonesia. Beliau telah mengemukakan sembilan kekeliruan yang sering ditimbulkan oleh GAH beserta dengan jawapannya. Segala kekeliruan yang ditimbulkan itu telah disahkan oleh tokoh-tokoh GAH iaitu Kassim Ahmad dan Othman Ali dalam satu sesi temubual yang berasingan dengan mereka berdua. Kajian beliau turut menggunakan kaedah soal selidik yang diedarkan kepada 100 orang awam di Malaysia dan di Indonesia. Sebanyak sepuluh soalan yang berhubung dengan kedudukan hadis dikemukakan untuk dijawab oleh responden. Menerusi soal selidik kajian beliau menunjukkan kesemua responden (100\%) mengakui bahawa hadis adalah undang-undang dan hujah dalam Islam. Mereka yang paling rendah ilmu agamanya tetap mengatakan bahawa hadis termasuk dalam hukum Islam. Kajian beliau juga mendapati pandangan umum umat Islam tentang GAH ialah mereka (GAH) ialah orang yang tidak faham tentang Islam dan orang yang menolak hadis bererti menolak Nabi S.A.W. dan Al-Qur'an.

Azmil Zainal Abidin (2005) dalam kertas kerjanya Pengeliruan Orientalis Terhadap Aspek Periwayatan Dan Sanad Hadis: Reaksi Usul-Din, memuatkan shubhah-shubhah yang dikemukakan oleh golongan anti hadis berhubung dengan punca mereka menolak hadis. Kemudian beliau nyatakan jawapan-jawapan terhadap shubhah-shubhah mereka. Penjelasan mengenai 'kesan' yang menumpukan kepada reaksi pelbagai pihak terhadap kewujudan dan keaktifan GAH, pengkaji mendapati sebilangan besar umat Islam, para pemimpin dan agensi-agensi agama kerajaan menentang keras kumpulan ini. Namun begitu, kajian ini juga mendapati segelintir umat Islam dan juga pemimpin menyokong dan mendokong gerakan ini. Sehubungan dengan itu, gerakan ini gagal dibenteras secara sepenuhnya oleh pihak berkuasa agama. Campur tangan sesetengah pemimpin mengakibat tindakan yang sepatutnya lebih keras dikenakan kepada mereka bertukar menjadi lebih ringan. Kadangkala, golongan ini didapati tidak bersalah dan boleh meneruskan penerbitan artikel-artikel mereka dalam surat-surat khabar atau majalah-majalah tempatan.

Berhubung dengan 'kesan atau pengaruh' pemikiran GAH pula didapati memang GAH telah berjaya mempengaruhi segelintir pemikiran umat Islam. Kesan pemikiran GAH terserlah dalam akidah, syariat umat Islam (Al'Ikhsan Ghazali \& Sawari, 2014) dan akhlak (Mohd AI'ikhsan Ghazali, Siti Salwa Md. Sawari \& Mohamad Muntaha Salleh, 2015). Perkara-perkara akidah yang sudah dipercayai sekian lama oleh umat Islam seperti kewujudan azab kubur, kemunculan Imam Mahdi, Nabi Isa a.s. dan banyak lagi telah mula dipertikaikan. Perkara-perkara syariat yang asas seperti kewajipan menutup aurat, hukuman bunuh bagi mereka yang murtad, malam lailatu al-qadr dan banyak lagi telah disyaki pensyariatannya. Terdapat di kalangan umat Islam yang mempercayai bahawa semua itu adalah karut dan diada-adakan oleh ulama-ulama terdahulu. Pengaruh GAH telah terpahat dalam pemikiran segelintir umat Islam. Semua pihak sama ada golongan profesional atau tidak, berpotensi untuk dipengaruhi oleh pemikiran GAH. Mereka yang kurang berminat belajar agama, lemah amal ibadah dan kawalan dirinya adalah lebih berisiko untuk dipengaruhi oleh GAH. Pengetahuan berhubung GAH yang dimiliki oleh umat Islam, berperasaan negatif dan bertingkah laku negatif terhadap GAH tidak boleh menjamin mereka terselamat daripada pengaruh GAH. Di sinilah hidayah daripada Allah berperanan menyelamatkan seseorang itu daripada terjerumus ke lembah kebinasaan. Doa sama ada daripada individu itu sendiri atau orang lain boleh membantu mendapat hidayah tersebut. Umat Islam pula mestilah sentiasa ingat mengingati antara satu sama lain. Budaya tegur menegur sesama rakan atau jiran akan mendatangkan keberkatan lalu mempastikan mereka sentiasa berada di jalan kebenaran. Bagi mereka yang tidak mendengar nasihat dan tidak boleh mengambil apa-apa pedoman daripada teguran orang, biarlah undang-undang yang mengajar mereka supaya menjadi teladan kepada orang lain. Undang-undang tidak boleh dikenakan kepada mereka sekiranya umat Islam masih berkepentingan sendiri dan tidak melaporkan kegiatan songsang yang mereka ketahui itu kepada pihak berkuasa. Pihak berkuasa sendiri mestilah sentiasa memberi kesedaran kepada umat Islam dan membuat pemantuan terhadap keaktifan ajaran-ajaran yang songsang (Ghazali, Yusof \& Md. Sawari, 2015).

\section{Objektif Kajian.}

i. Mengenal pasti langkah-langkah penyelesaian yang telah di amalkan oleh pihak kerajaan

ii. Mengenal pasti langkah-langkah penyelesaian yang telah di amalkan masyarakat Malaysia.

\subsection{METODOLOGI}

Di dalam kajian ini pengkaji menggunakan metode kajian kuantitaif. Pengkaji telah menggunakan dua kaedah untuk mengumpul data iaitu melalui kaedah kajian perpustakaan dan kaedah temubual.

\section{i. Kajian Perpustakaan}

Kajian secara perpustakaan ini digunakan untuk mencari maklumat yang berkaitan dengan pentakrifan, sejarah anti hadis di zaman lampau dan moden, ajaran-ajaran mereka, metodologi yang dipakai dan sebagainya. 
Bahan-bahan bagi kajian ini termasuklah buku-buku, akhbar, majalah, jurnal, kertas kerja dan sebagainya. Kajian perpustakaan turut melibatkan Internet yang sekarang ini telah menjadi gelanggang utama dan penting bagi aliran anti hadis untuk menyebarkan pemikiran mereka.

ii. Kaedah Temu bual

Kaedah ini digunakan dengan menemu bual individu-individu atau pihak-pihak tertentu yang terdiri daripada pelbagai pihak termasuk beberapa orang yang telah mengikuti beberapa program yang dianjurkan oleh gerakan anti hadis. Temu bual juga dilakukan terhadap beberapa tokoh agama dan wakil pihak jabatan agama di peringkat pusat dan negeri berhubung dengan isu anti hadis.

\subsection{PENEMUAN DAN PERBINCANGAN}

\section{Tindakan Kerajaan Dan Masyarakat}

Telah banyak tindakan yang telah diambil oleh pihak berkuasa khususnya pihak berkuasa agama sama ada di peringkat pusat mahupun negeri dalam menangani GAH ini. Tindakan drastik turut diambil oleh institut-institut pengajian tempatan dan individu-individu yang berprihatin terhadap isu ini untuk sama-sama membanteras dan mencegah fahaman ini daripada merebak dan menular.

\section{Tindakan Kerajaan}

Pihak kerajaan di peringkat pusat seperti JAKIM dan juga di peringkat negeri seperti Jabatan-jabatan agama telah mengambil pelbagai langkah untuk menangani gejala songsang ini daripada berleluasa.

a. Mengeluarkan Fatwa

Pada 19 Jun 1986, Jawatankuasa Fatwa Kebangsaan telah meneliti secara khusus terhadap buku "Hadis Satu Penilaian Semula" dan seterusnya menyimpulkan bahawa buku tersebut bercanggah dengan ajaran Islam dan orang yang menolak hadis sebagai sumber hukum adalah terkeluar daripada ajaran Islam. Jawatankuasa juga telah mengesyorkan kepada Kementerian Dalam Negeri supaya buku tersebut diharamkan (BAHEIS 1995). Jawatankuasa Fatwa Kebangsaan telah membuat keputusan berhubung dengan kumpulan anti hadis pada 9 Jun 1995 bahawa:

i. $\quad$ Mana-mana orang atau kumpulan orang yang berpegang kepada ajaran-ajaran dan fahaman-fahaman yang terkandung dalam buku "Hadis Satu Penilaian Semula", "Hadis Jawapan Kepada Pengkritik, "pendedahan Kebenaran Adalah Dari Tuhanmu, "Hadis Di Dalam Al-Qur'an”, "Bacaan”, “The Computer Speaks: God's Message To The World atau Risalah Iqra' adalah murtad.

ii. Mana-mana orang Islam adalah dilarang mengajar, mempelajari, mengamalkan, berpegang kepada atau menyebarkan ajaran-ajaran dan fahaman-fahaman yang terkandung dalam buku "Hadis Satu Penilaian Semula", "Hadis Jawapan Kepada Pengkritik, "pendedahan Kebenaran Adalah Dari Tuhanmu, "Hadis Di Dalam Al-Qur'an", "Bacaan", "The Computer Speaks: God's Message To The World atau Risalah Iqra'. Pejabat mufti Wilayah-Wilayah Persekutuan melalui Akta Pentadbiran Undang-undang Islam (Wilayah-Wilayah Persekutuan) 1993 di bawah seksyen 34 bertarikh 15 Januari 1996 telah mengeluarkan fatwa antara isinya adalah seperti berikut:

Bahawa mana-mana orang atau kumpulan orang yang berpegang kepada ajaran, pegangan atau fahaman yang terkandung di dalam buku atau risalah, isi kandungannya dan terjemahannya, yang disebut dalam subperenggan (A) adalah sesat kerana ia bertentangan dengan akidah, syariah dan akhlak Islam (Akta Pentadbiran Undang-Undang Islam (Wilayah-Wilayah Persekutuan) 1993, Fatwa Di Bawah Seksyen 34, Bertarikh 15 Januari 1996, (Jawi/A/145;Pn.(Pu2) 530). Pihak berkuasa agama di negeri-negeri seluruh Malaysia turut memfatwakan dan seterusnya mewartakan kesesatan ajaran anti hadis yang di bawa oleh Kassim Ahmad. Berikut disenaraikan negeri-negeri di Malaysia beserta dengan tarikh pewartaan dan nombor fatwa berkenaan dengan pengharaman ajaran anti hadis.

Berkenaan dengan ajaran $\mathrm{Hj}$. Khahar jawatankuasa Perundangan Majlis Agama Islam Selangor pada $28 \mathrm{Mac}$ 1991 telah memfatwakan ajaran ini adalah salah dan menyeleweng. Keputusan fatwa telah diwartakan pada 29 Ogos 1991 (JAKIM 2005).

b. Pengharaman Buku-Buku Dan Pertubuhan

Pada 7 Jun 1986, Kementerian Dalam Negeri secara rasminya telah mewartakan pengharaman buku "Hadis Satu Penilaian Semula" setelah disyorkan oleh Jawatankuasa Fatwa Kebangsaan (BAHEIS 1995).

c. Sesi Muzakarah

Jabatan Agama Islam Selangor (JAIS) telah mengadakan muzakarah dengan $\mathrm{Hj}$. Abdul Kahar dan beberapa orang pengikutnya beberapa kali dalam tahun 1990, termasuk secara formal sebanyak dua kali yang dipengusikan oleh S.S. Mufti Negeri. JAIS juga telah mengadakan Majlis Penjelasan Akidah kepada pengikut-pengikut ajaran ini pada 24 Febuari 1998 dengan kerjasama JAKIM dan beberapa orang tempatan. Satu perjumpaan telah diadakan di antara Bahagian Penyelidikan JAKIM dengan Hj. Khahar dan pengikutnya pada 15 Mac 1998 di rumah Haji Khahar di Kg. Kemesah, Hulu Kelang (JAKIM 2005). 


\section{d. Penerbitan}

Pada 1986 majlis Agama Islam Kelantan telah menerbitkan sebuah buku yang bertajuk "Salah Faham Terhadap Hadis" tulisan Hj. Ismail Hj. Yusof. Pada 25 Ogos tahun yang sama juga Persatuan Bekas Mahasiswa Timur Tengah telah melancar sebuah buku bertajuk "Penjelasan Mengenai Hadis Dan Kod 19" yang ditulis oleh Dr. Mahayudin Hj. Yahya, Dr. Huda Mohsen dan Dr. Fatah Haron. Haji Said Ibrahim telah menulis buku yang bertajuk "Penolakan Terhadap Penilaian Semula Hadis" pada tahun 1987 terbitan Media Hasda. Fakulti Pengajian Islam telah menerbitkan buku yang bertajuk Jawapan Kepada Buku Hadis Satu Penilaian Semula yang ditulis oleh Dr. Harun Din dan rakan-rakan pada 1988.

Pada tahun 1995 Bahagian Hal Ehwal Islam, Jabatan Perdana Menteri telah menerbitkan sebuah buku yang bertajuk "Penjelasan Terhadap Fahaman Anti hadis". Bahagian Penyelidikan Jabatan Agama Wilayah Persekutuan telah mengeluarkan satu senarai ajaran-ajaran sesat semenjak 1997-2004 yang memuatkan nama ajaran, pengasas, kawasan muncul, ciri-ciri kesalahan, tarikh fatwa dan pewartaan.

e. Penyebaran Risalah

Pihak berkuasa agama turut mengambil tindakan menyebarkan risalah-risalah percuma kepada masyarakat dalam rangka memberi hebahan dan kesedaran kepada masyarakat berhubung bahayanya golongan-golongan yang menyeleweng.Sebagai contohnya risalah yang dikeluarkan oleh Jabatan Agama Islam Selangor (JAIS) pada Julai 2006 yang bertajuk "Tips-tips Mengenali Ajaran Menyeleweng". Risalah berkenaan menyenaraikan 31 kaedah mengenali sesuatu ajaran itu menyeleweng atau tidak (JAIS 2006). Risalah berkenaan dengan ajaran, fahaman dan tarikat yang telah difatwakan dan diwartakan menyeleweng telah dikeluarkan oleh JAWI untuk menyedarkan masyarakat wujudnya golongan yang sesat dan menyeleweng di Malaysia.

\section{f. Pendedahan Di Akhbar}

Akhbar harian Kosmo pada hari Khamis 18 Mei 2006 telah menyenaraikan 23 ajaran sesat di Selangor. Akhbar itu juga memetik kata-kata Mufti Selangor berhubung dengan golongan yang terpengaruh dan menjadi pengikut ajaran sesat ini di mana mereka bukan sahaja golongan yang cetek ilmu pengetahuan agamanya malah golongan profesional dalam bidang agama juga tidak terlepas.

\section{Tindakan NGO Dan Masyarakat}

Badan-badan bukan kerajaan (NGO) terutama yang berlatarbelakangkan Islam turut berperaan menyekat penyebaran fahaman dan pemikiran ajaran ini. Selain pihak berkuasa dan badan-badan bukan kerajaan, terdapat juga di kalangan orang ramai yang turut melibatkan diri dalam usaha menangani penyebaran fahaman GAH ini.

a. Membuat Aduan

Tindakan-tindakan yang telah dibuat selama ini oleh pihak berkuasa adalah berdasarkan aduan-aduan yang telah diberikan oleh orang ramai. Tanpa aduan daripada orang ramai pihak berkuasa sudah pasti tidak akan dapat melaksanakan kerja-kerja mereka dengan sempurna.

b. Penulisan

Pada tahun 1991 sebuah buku yang bertajuk "Islam dan Hadis: Satu Analisis Ke atas Usaha-Usaha Merosakkan Peribadi Dan Autoriti Rasullullah S.A.W.” telah diterbitkan oleh anggota-anggota panel ABIM yang dipengerusikan oleh Dr. Abdul Halim ElMuhammady. Buku ini secara khusus menjawab isu-isu yang dikemukan oleh Kasim Ahmad dalam bukunya "Hadis Satu Penilaian Semula".Amnah Bahari dalam tesis masternya yang bertajuk "Critical Analysis of Kassim Ahmad's Controversial Issues on Hadis in Hadis Satu Penilaian Semula" telah menjawab secara khusus buku karangan Kassim Ahmad tersebut. Zulkifli Mohd juga melalui tesis masternya yang bertajuk "Anti-Sunnah Movement and its Impact on the Muslim Ummah" telah menghutarakan pemikiran Rashad Khalifa dan Kassim Ahmad berhubung dengan hadis dan di sudahi dengan kesannya kepada umat Islam.Mohd Hafiz Firdaus Abdullah telah menulis buku yang bertajuk "20 Hujjah Golongan Anti hadis Dan Jawapannya" pada tahun 2002 yang diterbitkan oleh Perniagaan Jahabersa.

c. Pendedahan Di Akhbar

Penyelaras Projek Persatuan Pengguna Islam Malaysia (PPIM), Noor Nirwandy Mat Nordin, telah mendedahkan di Harian Metro 17hb January, 2006 kewujudan gerakan anti hadith yang bertujuan menyebarkan kepercayaan, amalan dan pemikiran berlandaskan al-Al-Qur'an semata-mata. Beliau berkata pihaknya mengesan aktiviti golongan itu di internet yang boleh memberi kesan tidak baik kepada generasi muda.

\subsection{KESIMPULAN}

GAH wujud di Malaysia sejak tahun 1984. Ia dipelopori oleh golongan intelek dan dibantu oleh mereka yang berpengaruh. Setelah diharamkan mereka bergerak secara rahsia dan menyelinap masuk ke dalam fahaman-fahaman lain yang seiringan dengan mereka dalam mempertikaikan sistem nilai dan hukum Islam. Mereka terus bergerak dalam berbagai cara dan menggunakan segala kesempatan yang ada. 
Tindakan tidak boleh diambil ke atas mereka kerana ketiadaan laporan. Lantaran itu bukti-bukti kewujudan pergerakan kumpulan mereka sukar diperoleh. Penggunaan Internet menjayakan lagi penyebaran fahaman mereka di samping sukar dijejaki oleh pihak berkuasa. Golongan yang tiada pengetahuan asas berhubung dengan Islam akan mudah terpengaruh dengan fahaman mereka. Golongan yang sudah mula jinak dengan ajaran anti hadis itu pula tidak akan ditegur atau dinasihati oleh sesiapa dan dia sendiri pun tidak bertanya kepada sesiapa. Fenomena ini akan menyemarakkan lagi pemikiran anti hadis dan mesti ditangani segera. Dapatan daripada kajian boleh menjadi garis panduan dalam memaksimumkan pembanterasan kemelut Golongan Anti Hadis daripada tersebar luar. Bukan itu sahaja kajian ini di harapkan dapat membantu para ahli akademik untuk mengenalpasti kesan-kesan penyelesain yang telah terlaksana. Sehubungan dengan itu satu kajian lanjut diperlukan untuk mengesan sejauh mana pemikiran GAH telah mempengaruhi dan memberi kesan kepada masyarakat. Hasil daripada penyelidikan ini amat berguna untuk semua pihak.

\section{Rujukan}

Al'Ikhsan Ghazali, M., \& Sawari, S. S. (2014). The Influence of anti Hadith Group (gah) Thinking on the Muslim Ummah: A Special Study in the Klang Valley. Pengaruh Pemikiran Golongan anti Hadith (gah) Kepada Umat Islam: Kajian Khusus di Lembah Klang. Al-Bayan: Journal of Qur'an and Hadith Studies, 12(1), 75-86.

Al-Sibaci, Mustaffa al-Sibaci. (1985). Al-Sunnah Wa Makanatuha Fi Al-Tasric Al-Islami. Edisi ke-4. al-Maktab al-Islami, Beirut.

Al-Zahrani, Muhammad ibn Matr. (1992). Tadwin Al-Sunnah Al-Nabawiyyiah. Ed.baru. Maktabah al-Siddiq, Taif.

Baheis, Bahagian Hal-Ehwal Agama Islam. (1987). Kedudukan Sunnah Dalam Islam. Ed. baru. Jabatan Perdana Menteri, Kuala Lumpur.

Deden Suparman. (2003). Anti Hadis Dan Engkar Sunnah: Suatu Kajian Perbandingan Antara Malaysia Dan Indonesia. Tesis Sarjana Usuluddin, Jabatan Sejarah Dan Tamadun Islam, Akademi Pengajian Islam, UM.

Ghazali, M., Md. Sawari, S., \& Yusuf, M. (2015). "The Severity of Anti Hadith Groups (AHG) Thought: Solutions, Challenges and Barriers". Mediterranean Journal Of Social Sciences, 6(3S2), 127. Diakses dari: http://www.mcser.org/journal/index.php/mjss/article/view/6473/6203.

Ghazali, M., Yusof, M., \& Md. Sawari, S. (2016). "An Analysis On The Public Perceptions And Awareness Towards The Issues Of The Anti-Hadith In Klang Valley”. Mediterranean Journal Of Social Sciences, 7(2S2), 385-392.

Ghazali, M., Yusof, M., \& Md. Sawari, S. (2016). "Mosque as a Platform to Address The Issues of The Anti-Hadith In Malaysia". Mediterranean Journal Of Social Sciences, 7(2S2), 553-559.

Habeeb Rahman Ibramsa. (2004). Pemikiran Antihadis Dan Perkembangan Semasa. Kertas kerja Seminar Hadis: Cabaran Dan Masa Depan. Anjuran UKM dan KUIS. Bangi, Selangor, 13 Mac.

Hafiz Firdaus Abdullah. (2002). 20 Hujah Golongan Antihadis Dan Jawapan. Johor Bahru: Perniagaan Jahabersa.

Kamus Dewan. (2002). Edisi ke-3. Dewan Bahasa dan Pustaka, Kuala Lumpur.

Mahmud Zuhdi . (1994). Beberapa Pemikiran Tentang Ijtihad, Islah Dan Tajdid. Dewan Bahasa dan Pustaka, Kuala Lumpur.

Maik, Majlis Agama Islam Kelantan. (1986). Salah Faham Terhadap Hadis: satu penjelasan. Ed. baru.Maik, Kota Bharu.

Mat, J. (2015). Ghuluwdalam Akidah Islam: Satu Pengenalan Ringkas. Jurnal Usuluddin, 5(5), 87-111.

Mohd AI'ikhsan Ghazali, Siti Salwa Md. Sawari \& Mohamad Muntaha Salleh. (2015). Penyebaran Fahaman Anti Hadis Dan Kesannya Terhadap Akhlak. National Research Seminar. Universiti Sultan Idris. 4 April 2015.

Muhammad Baha' al-Din. (1999). al-Mustashrikun wa al-hadith al-nabawi. Ed. baru. Dar al-Fajr dan Dar al-Nafais, t.tp.

Nor, M. R. M. (2011). Menangani Cabaran Umat Islam Era Moden. Jurnal Al-Tamaddun, 6, 107-121.

Nur al-Din cItr.( 1996). Manhaj al-naqd fi ulum al-hadith. Edisi ke-3. Beirut Dar al-Fikr.

Nurfajriyani, S. (2015). Ingkar Hadis Di Indonesia Dan Malaysia. Studi Kritis Pemikiran Hadis Nazwar Syamsu Dan Kassim Ahmad. Doctoral Dissertation, Uin Sunan Kalijaga Yogyakarta.

Said Ibrahim. (1987). Penolakan terhadap penilaian semula hadis. Media Hasna, Kuala Lumpur.

Sulidar, S. (2010). Liberalisme Golongan Inkarussunnah Di Indonesia Dan Malaysia. MIQOT: Jurnal Ilmu-ilmu Keislaman, $34(2), 193-206$ 